Relations industrielles

Industrial Relations

\title{
Robert Lescarbeau, Maurice Payette et Yves St-Arnaud, Profession: consultant
}

\section{Laurent Bélanger}

Volume 46, numéro 2, 1991

URI : https://id.erudit.org/iderudit/050689ar

DOI : https://doi.org/10.7202/050689ar

Aller au sommaire du numéro

Éditeur(s)

Département des relations industrielles de l'Université Laval

ISSN

0034-379X (imprimé)

1703-8138 (numérique)

Découvrir la revue

Citer ce compte rendu

Bélanger, L. (1991). Compte rendu de [Robert Lescarbeau, Maurice Payette et Yves St-Arnaud, Profession: consultant]. Relations industrielles / Industrial

Relations, 46(2), 490-491. https://doi.org/10.7202/050689ar

Tous droits réservés (C Département des relations industrielles de l'Université Laval, 1991
Ce document est protégé par la loi sur le droit d'auteur. L’utilisation des services d'Érudit (y compris la reproduction) est assujettie à sa politique d'utilisation que vous pouvez consulter en ligne.

https://apropos.erudit.org/fr/usagers/politique-dutilisation/ 
Herrick's proposals can be criticized as impractical and unrealistic. Herrick presents four examples: the Cadillac assembly plant in Detroit-Hamtramck, the Shell chemical plant in Sarnia, Ontario, the Saturn assembly plant in Tennessee, and the Pima County government in Arizona. None of these organizations fully meet his principles of design even though all but the governmental unit of Pima County are greenfield sites. If it is difficult to establish his model in a greenfield site, consider all the added problems of trying to impose a complicated system of committees in an established work site.

Traditional or bureaucratic organizations which exert control from the top down are also becoming impractical because they do not mobilize the best efforts of people in the organization. Much of Herrick's book is given over to very effective criticism of current practices, such as leadership, training and remuneration, which are not well suited to employee participation. Not only do these practices need to be changed, but so does much of the thinking that has led to such practices.

In the final portion of the book Herrick describes what labor and management must do to create a system of joint management. Labor must bargain for joint management and participative practices that would improve the situation of the employees as well as that of the company. Management must also change its current practices such as concern for management rights which prevent establishing effective organizations.

This book can be helpful to both labor and management by challenging current practices and narrow thinking which do not advance the interests of the company, union or the employees. The book can stimulate new ideas and new efforts at collaboration between union and management. Greater collaboration, either inside or outside the labor contract, is necessary in order for organizations to be competitive and offer a satisfactory quality of work life.

Bernard PoRTIS

The University of Western Ontario

Profession: consultant, par Robert Lescarbeau, Maurice Payette et Yves St-Arnaud, Montréal, Les Presses de l'Université de Montréal, 1990, 341 p., ISBN 2-7606-1539 (PUM) et ISBN 2-7384-0862-1 (L'Harmattan)

Il s'agit d'une réédition d'un ouvrage écrit par les mêmes auteurs intitulé: Devenir consultant: un instrument autogéré de formation. On se souvient que ce premier ouvrage se présentait sous deux tomes: un premier faisant état du modèle d'intervention proposé par les auteurs et un recueil de cas incluant un corrigé; un deuxième contenant les instruments développés par ces mêmes auteurs et supportant l'utilisation du modèle. Le fait de se promener continuellement d'un tome à l'autre créait un inconvénient majeur tant au plan de la lecture que de l'utilisation du manuel, puisqu'il s'agissait bel et bien alors d'un manuel.

Les auteurs ont ici saisi l'occasion d'insérer dans un seul volume la partie théorique, quelques dialogues commentés et les principaux instruments utilisés au cours d'une intervention auprès d'un groupe, d'une organisation ou d'une communauté. L'ouvrage devient alors d'une lecture plus facile, retenant l'attention du lecteur en lui permettant de trouver en un même endroit l'ensemble de l'information que les auteurs veulent ainsi véhiculer.

L'ouvrage comporte trois parties: une première où le modèle d'intervention proposé est bien décrit et expliqué, avec à l'appui un cas servant d'exemple, d'illustration ou d'exercice; 
une deuxième où l'on retrouve, faisant l'objet de chacun des chapitres respectifs, les six phases d'une intervention facilitant le changement: l'entrée, le contrat, l'orientation (recadrage ou diagnostic), la planification des actions de changement, la réalisation et la terminaison (suivi). Enfin, une troisième partie traite plus spécifiquement de la relation de collaboration qui doit s'établir entre l'intervenant externe et le système-client (le groupe ou l'organisation qui est à l'origine d'une demande d'aide). Pour une lecture plus fructueuse de l'ouvrage, il serait utile de rappeler ici que la notion de consultation retenue et illustrée par les auteurs diffère sensiblement de la notion usuelle qui fait du consultant un conseiller-expert, c'est-à-dire une personne spécialisée dans un domaine de la gestion ou des sciences du comportement, se chargeant d'établir un diagnostic et de proposer des recommandations.

Il s'agit plutôt ici d'une notion de consultation qui s'inscrit dans une relation d'aide, dans une démarche de développement organisationnel ou de développement communautaire. En effet, ce type de consultation se distingue par au moins une caractéristique: celle d'engager les personnes concernées dans la conduite d'un diagnostic, l'élaboration des orientations à donner au changement. À ce sujet, nous croyons que les auteurs auraient dû, dès le point de départ, bien préciser à quelle enseigne ils se logeaient en faisant toutes les distinctions qui s'imposent entre la consultation conventionnelle ou d'expertise, le changement planifié, le développement organisationnel, le développement communautaire. Nous croyons que le rôle du consultant et les habiletés exigées diffèrent quelque peu au passage d'un milieu ou d'un type d'intervention à un autre.

Ces petites lacunes mises à part, il nous faut bien reconnaître que les auteurs ont su très bien allier la théorie à la pratique tout en fournissant un minimum d'instruments appropriés, sans ajouter à la complexité du sujet.

Laurent BÉLANGer

Université Laval

Capitalism and Modernity: An Excursus on Marx and Weber, by Derek SAYER, London and New York, Routledge, 1990, 10+164 p., ISBN 415-01728-9.

According to Webster, modernity means the state or quality of being modern. Sayer is interested in something else, namely how Marx and Weber understood the relationship between capitalism and modernity and what is the meaning of it for our present day understandings. When for the first of them capitalism was the demiurge of modern society, the second saw rationalization as the basic factor of progress. "Severance of the material means of a given human activity from its agents (which, just as for Marx, implies their isolation as solitary individuals) is the generic basis of all institutional rationalization. This is the key principle of that bureaucracy which for Weber pervades most arenas of modern life..." (p. 13). People more or less willingly accept the depersonalized order for the benefits which it offers to them; they are actually forced to subdue to the formalized rules and expectations because no alternative is available to them; the distinction of the "personal" from the "official" is fully implemented and this has several substantial consequences. According to Sayer, "the most significant of Weber's echoes of Marx lie in the contrast both draw between personalized and impersonal modes of administration and forms of power, and the bases of their legitimacy" (p. 141). The view of Marx is that modernity means the rule of individuals by abstractions whereas previously they were dependent on one another. 